Int. J. Electrochem. Sci., 12 (2017) $2777-2790$

International Journal of

ELECTROCHEMICAL

SCIENCE

www.electrochemsci.org

\title{
Electrochemical Degradation of Phenol Wastewater by Sn-Sb- Ce Modified Granular Activated Carbon
}

\author{
Ping Li, Wangfeng Cai, Yue Xiao, Yan Wang ${ }^{*}$, Jiangyang Fan \\ School of Chemical Engineering and Technology, Tianjin University, Tianjin, 300354, China \\ *Email: wangyan170112@126.com
}

doi: $10.20964 / 2017.04 .58$

Received: 13 January 2017 / Accepted: 4 March 2017 / Published: 12 March 2017

Electrochemical degradation of phenol wastewater using $\mathrm{Sn}-\mathrm{Sb}$-Ce modified granular activated carbon (SCG) particle electrode was investigated. The electro-catalytic performance of different SCG electrodes were investigated by cyclic voltammetry $(\mathrm{CV})$ and polarization plots. The scanning electron microscope accompanied with energy dispersive X-ray spectroscopy (SEM-EDS), X-ray diffraction (XRD) and Brunauer-Emmett-Teller (BET) were investigated in order to characterize the surface morphology of SCG particle electrode. The effects of volume flow rate, current density and initial $\mathrm{pH}$ value on removal of phenol and chemical oxygen demand (COD) were studied. Results demonstrated that at volume flow rate of $0.15 \mathrm{~L} \mathrm{~min}^{-1}$, current density of $25 \mathrm{~mA} \mathrm{~cm}$ and initial $\mathrm{pH}$ value of 3 , the optimal phenol and COD removal could reach $88.93 \%$ and $84.21 \%$. Average current efficiency (ACE) and energy consumption (EC) were $16.25 \%$ and $0.2474 \mathrm{KWh} \mathrm{gCOD}^{-1}$, respectively. These results demonstrated that SCG electrode would be a promising particle electrode for electrochemical degradation of phenol.

Keywords: Electrochemical degradation; particle electrode; phenol wastewater; three-dimensional electrode; COD removal

\section{$\underline{\text { FULL TEXT }}$}

(C) 2017 The Authors. Published by ESG (www.electrochemsci.org). This article is an open access article distributed under the terms and conditions of the Creative Commons Attribution license (http://creativecommons.org/licenses/by/4.0/). 